ing and size,-bear, in the general style of the bold wavy ridges of their exposed orerlying portions, a character which there is no mistaking, no matter what their position.

Yours truly,

March 12, 1863.

W. Davies.

\title{
The Rev. W. Allen's Letter on Portland Fissures.
}

Sir,-Will you allow me to say a few words on the subject of Mr. Allen's letter in your last number $P$ If his suggestion be correct, how is it that animals of distinct gener $\alpha$, if not species, from any known to have inhabited Britain in historic times are found in the Middle and Upper Oolite? And, again, if he be right concerning the "Upper Oolite" of Portland, why may not the same have taken place with other geological formations after the Oolitic series? And this we know cannot well be, as those succeeding it must be far older than 6-7000 years. Is it not more likely that during the Pliocene period (when man is supposed to have existed), the "Upper Oolite" of Portland was submerged; and, as the remains of an extensive estuary (in Dorset and Hampshire) exist close at hand, may not the human remains referred to by Mr. Allen have been washed down to the sea and so deposited in the submerged strata, than that a fresh sedimentary deposit has taken place, and the whole forma. tion have been again upraised, and rent almost throughout, perhaps by volcanic action? Hoping you will excuse these perhaps somewhat crude remarks,

Woodlands, Thorpe, near Noruich, March 23.

I remain, yours truly,

Charles Jicks, Jun.

\section{Norway Horses.}

Sir,-At p. 26 of the 'Geologist' is an inquiry about the teeth of Norway horses. Last autumn, in a Norwegian tour, a friend, Charles Montagu Doughty, Esq., picked up by the sea, and near the North Cape, the tooth of a horse-which molar I have forgotten. It had not the aspect of a fossil, nor was it very recent, but, as Mr. Doughty suspected before I saw it, was certainly Equus fossilis. Although I have often found on our own coasts teeth of Equus caballus in exactly the same state of preservation, this cannot be regarded as more than suggestive evidence of the existence of the fossil form, since horses are not now kept so far north. I am, Sir, faithfully yours,

Cambridge, March 9, 1863. Harky Segley.

\section{PROCEEDINGS OF GEOLOGICAL SOCIETIES.}

Georogicar Societr.-February 18th, 1863.-." On the Middle and Upper Lias of the Dorsetshire Coast." By E. C. H. Day, Esq.

The subdivisions of the Lias instituted by Sir Henry de la Beche and 